\title{
PENGGUNAAN METODE DRILL DALAM MATERI GERAKAN DAN BACAAN SALAT PADA PESERTA DIDIK SD NEGERI SEKARAN 02 GUNUNGPATI SEMARANG
}

\author{
Siti Rosidah \\ Sekolah Dasar Negeri Sekaran 02 Gunungpati, Semarang \\ rosida25ida@gmail.com
}

\begin{abstract}
Abstrak
Penelitian tindakan kelas ini menerapkan metode drill dengan tujuan untuk meningkatkan aktivitas dan hasil belajar peserta didik kelas III semester genap di SD Negeri Sekaran 02 Gunungpati Semarang tahun ajaran 2018/2019 pada materi bacaan dan gerakan salat. Permasalahan yang ingin dikaji dalam penelitian ini adalah: (1) Apakah penerapan metode drill dalam pembelajaran PAI semester 2 materi gerakan dan bacaan salat di SD Negeri Sekaran 02 Gunungpati Semarang, (2) Bagaimana efektifitas pelaksanaan pembelajaran Pendidikan Agama Islam menggunakan metode drill materi gerakan dan bacaan salat di SD Negeri Sekaran 02. Penelitian ini menggunakan penelitian tindakan kelas (action research) sebanyak dua siklus. Setiap siklus terdiri atas empat tahap yaitu: rancangan, kegiatan dan pengamatan, refleksi, dan revisi. Sasaran penelitian ini adalah siswa kelas III SD Negeri Sekaran 02 Kecamatan Gunungpati Kota Semarang tahun pelajaran 2018/2019. Data yang diperoleh berupa hasil tes formatif dan lembar observasi kegiatan belajar mengajar. Hasil analisis didapatkan bahwa prestasi belajar siswa mengalami peningkatan dari siklus I sampai siklus II yaitu, siklus I $60 \%$, siklus II $80 \%$. Hasil penelitian ini mengungkapkan bahwa metode drill dapat berpengaruh positif terhadap hasil belajar siswa kelas III semester II pada kompetensi dasar menghafal bacaan salat dan menampilkan keserasian gerakan salat sangat efektif.
\end{abstract}

Kata kunci: metode drill, pembelajaran PAI, gerakan dan bacaan salat.

\begin{abstract}
This classroom action research applies drill method to increase activity and learning outcomes for third graders in semester 2 at SD Negeri Sekaran 02 Gunungpati Semarang year 2018/2019 on material salat movement and reading. Problems studied in this research are: (1) Is the application of drill method in Islamic Education (PAI) lesson semester 2 on material salat movement and reading at SD Negeri Sekaran 02 Gunungpati Semarang, (2) How is the effectiveness of implementation Islamic Education lesson using drill method on material salat movement and reading at SD Negeri Sekaran 02. This study used action research in two cycles. Each cycle consists of four stages, they are: design, activities and observations, reflection, and revision. The target of this research is third graders at SD Negeri Sekaran 02, Gunungpati, Semarang, year 2018/2019. The data obtained are in formative test results, observation sheets of teaching learning activities. From analysis result, the writer found that student learning achievement had increased from cycle I to cycle II, in cycle I is $60 \%$ and cycle II is $80 \%$. The results of this study reveal that drill method give positive effect on learning outcomes of third graders semester 2 on basic competence of memorizing salat reading and practicing salat movements in harmony effectively.
\end{abstract}

Keywords: drill method, Islamic education lesson, salat movements and reading. 


\section{A. PENDAHULUAN}

Pendidikan merupakan salah satu sarana untuk menentukan terciptanya tujuan pembangunan nasional, upaya dasar pembentukan pribadi manusia sebagai warga negara yang beriman dan bertaqwa kepada Tuhan Yang Maha Esa, budi pekerti luhur dan berkemampuan serta berketerampilan dasar sebagai bekal untuk pendidikan selanjutnya atau bekal hidup dalam masyarakat. Pada dasarnya siswa SD Negeri Sekaran 02 rajin dalam menjalankan ibadah shalat karena rata-rata dari mereka bertempat tinggal di lingkungan masjid atau mushola. Melalui metode drill siswa dengan mudah dan cepat dalam mempraktikkan ibadah salat sehingga dapat meningkatkan pembelajaran ibadah salat dengan baik dan benar. Penelitian ini menerapankan metode drill dalam pembelajaran PAI semester 2 materi gerakan dan bacaan salat di SD Negeri Sekaran 02 Gunungpati Semarang.

Pendidikan Agama Islam (PAI) adalah segala usaha untuk memelihara Fitrah manusia, serta sumber daya insani yang ada pada menuju terbentuknya manusia seutuhnya (Insan Kamil) sesuai dengan norma Islam. ${ }^{1}$ Pengertian yang dikemukakan Achmadi tersebut mengandung arti bahwa dalam proses Pendidikan Agama Islam terdapat usaha memelihara kesucian manusia, hal itu merupakan fitrah yang ada sejak lahir serta mengembangkan segala potensi jiwa yang terdapat padanya melalui segenap usaha, sehingga manusia tersebut terbentuk menjadi manusia yang sempurna berdasarkan pandangan Islam. Pada dasarnya tujuan Pendidikan Agama Islam identik dengan tujuan hidup manusia. Secara umum, tujuan Pendidikan Agama Islam adalah arah yang diharapkan setelah subyek didik mengalami perubahan proses pendidikan, baik pada tingkah laku individu dan kehidupan pribadinya maupun kehidupan masyarakat dan alam sekitarnya

Metode drill merupakan salah satu metode pembelajaran yang dapat sebutan latihan atau ulangan, maksudnya agar siswa dapat memiliki dan menguasai pengetahuan dan kecakapan tertentu, meskipun metode drill juga memiliki kelebihan dan kelemahan. Biasanya dalam metode drill (latihan atau ulangan) hanyalah untuk sekedar mengukur sejauh mana para siswa telah menyerap pembelajaran tersebut. Dengan demikian, metode drill akan meningkatkan efektifitas pembelajaran Pendidikan Agama Islam.

\footnotetext{
${ }^{1}$ Achmadi, Ideologi Pendidikan Islam. Yogyakarta: Pustaka Pelajar, 2005, hlm. 28
} 
Penilaian hasil belajar siswa kelas III SD Negeri Sekaran 02 pada mata pelajaran Pendidikan Agama Islam menunjukkan rendahnya tingkat penguasaan siswa terhadap materi pelajaran. Hal ini dapat penulis temui pada saat mengadakan ulangan pada mata pelajaran Pendidikan Agama Islam, jumlah 20 siswa hanya 5 siswa yang mendapat nilai 66 ke atas, bahkan 15 siswa memperoleh nilai rata-rata 55,25.

Hal inilah yang mendorong dilakukannya penelitian untuk mengadakan refleksi terhadap pembelajaran yang telah dilakukan untuk mendapatkan jawaban tentang kesulitan yang dihadapi siswa yang kemudian hasilnya dituangkan dalam bentuk laporan perbaikan pembelajaran melalui penelitian tindakan kelas untuk mata pelajaran Pendidikan Agama Islam. Permasalahan dari penelitian ini adalah (1) Apakah penerapan metode drill dalam pembelajaran PAI semester 2 materi gerakan dan bacaan salat di SD Negeri Sekaran 02, Gunungpati Semarang, (2) Bagaimana efektifitas pelaksanaan pembelajaran Pendidikan Agama Islam dengan menggunakan metode drill materi gerakan dan bacaan sholat di SD Negeri Sekaran 02. Tujuan penelitian ini yaitu untuk meningkatkan aktivitas dan hasil belajar peserta didik kelas III semester genap di SD Negeri Sekaran 02, Gunungpati Semarang Tahun Ajaran 2018/2019 pada materi bacaan dan gerakan salat.

Metode pembelajaran yang sering digunakan pada kegiatan pembelajaran berbasis aktivitas belajar peserta didik adalah metode drill. Metode drill berasal dari metode pengajaran Herbart yaitu metode assosiasi dan ulangan tanggapan untuk memperkuat tanggapan pelajaran pada peserta didik. Pelaksanaan secara mekanis untuk mengajarkan berbagai mata pelajaran dan kecakapan, sehingga menimbulkan verbalisme pengetahuan peserta didik, kebiasaan menghafal secara mekanis tanpa pengertian. Pengertian tersebut menunjukkan bahwa metode drill merupakan metode pembelajaran yang dilaksanakan dengan cara mengulang-ulang materi pembelajaran yang disampaikan melalui kegiatan pelatihan. ${ }^{2}$

Secara gramatikal kata drill berarti berlatih mengeja kata, menghapal, dan lain sebagainya, sehingga dapat disimpulkan bahwa drill adalah latihan dengan praktek yang dilakukan berulang kali atau kontinyu untuk mendapatkan keterampilan dan ketangkasan praktis tentang pengetahuan yang dipelajari. ${ }^{3}$ Penjelasan tersebut menunjukkan bahwa metode drill merupakan metode pembelajaran yang menekankan

\footnotetext{
${ }^{2}$ Roestiyah, Strategi Belajar Mengajar,Jakarta: Rineka Cipta, 2008, hlm. 112

${ }^{3}$ Suparno, Mengembangkan Profesionalitas Guru, Jakarta: Depdiknas, 2008, hlm 73
} 
pada pelatihan terhadap berbagai kecakapan tertentu pada diri peserta didik. Metode drill disebut juga metode latihan atau training merupakan suatu cara melaksanakan pembelajaran yang baik untuk menanamkan kebiasaan-kebiasaan tertentu. Selain itu metode drill merupakan metode pembelajaran yang digunakan agar peserta didik dapat memperoleh suatu ketangkasan, ketepatan, kesempatan dan keterampilan. ${ }^{4}$ Pengertian tersebut diperjelas oleh Sudjana yang menyatakan, "Metode drill adalah metode dalam pembelajaran dengan melatih peserta didik terhadap bahan yang sudah diajarkan atau berikan agar memiliki ketangkasan atau ketrampilan dari apa yang telah dipelajari". 5

Berdasarkan beberapa penjelasan menurut para ahli mengenai metode drill dapat disimpulkan bahwa metode drill adalah metode pembelajaran yang menggunakan teknik latihan dengan praktik yang dilakukan berulang kali secara kontinyu untuk mendapatkan keterampilan dan ketangkasan praktis tentang pengetahuan yang dipelajari. Metode drill merupakan metode pembelajaran yang dilaksanakan dengan memberikan berbagai bentuk pelatihan sesuai materi pembelajaran agar menjadi suatu kebiasaan dan kecakapan yang dimiliki peserta didik.

Metode drill mempunyai karaktertistik sebagai berikut: 1) Model pembelajaranya bersifat latihan. 2) Mengajarkan sebuah kebiasaan dalam pembelajaran. 3) Menambah kecepatan, ketepatan, dan kesempurnaan dalam menerima pembelajaran. 4) Memperkuat tanggapan pada siswa ${ }^{6}$. Tujuan penggunaan metode drill adalah sebagai berikut: 1) Memiliki ketrampilan moroeis/gerak, misalnya menghafal katakata, menulis, mempergunakan alat, membuat suatu bentuk, atau melaksanakan gerak dalam olah raga. 2) Mengembangkan kecakapan intelek, seperti mengalikan, membagikan, menjumlah, tanda baca, dll. 3) Memiliki kemampuan menghubungkan antara suatu keadaan, misalnya hubungan sebab akibat banyak hujan maka akan terjadi banjir, antara huruf dan bunyi, dll. 4) Dapat menggunakan daya pikirnya yang makin lama makin bertambah baik, karena dengan pengajaran yang baik maka anak didik akan menjadi lebih baik teratur dan lebih teliti dalam mendorong ingatannya dan 4) Pengetahuan anak didik akan bertambah dari berbagai segi dan anak didik tersebut akan memperoleh pemahaman yang lebih baik dan lebih mendalam. ${ }^{7}$

\footnotetext{
${ }^{4}$ Djamarah, Syaiful Bahri, Strategi Belajar Mengajar, Jakarta: Rineka Cipta, 2010, hlm. 108

${ }^{5}$ Nana Sudjana, Berbagai Metode Pembelajaran Aktif dan Kreatif. Jakarta: Bumi Aksara, 2012, hlm. 76

${ }^{6}$ Sumiati dan Azra, Metode Pembelajaran, Bandung: CV. Wacana Prima, 2008, hlm. 105

${ }^{7}$ Arief, Armai, Pengantar Ilmu dan Metodologi Pendidikan Islam. Jakarta: Intermasa, 2002, hlm.
} 
Metode drill dilaksanakan dengan menekankan latihan kecakapan peserta didik secara berulang-ulang. Latihan dapat dilaksanakan perseorangan, kelompok, ataupun klasikal. Menentukan apakah latihan yang dilakukan bersifat perseorangan, kelompok, atau klasikal didasarkan atas memadai atau tidak sarana dan prasarana. Selain itu, penentuan bentuk pelatihan juga didasarkan atas berbagai pertimbangan pendidik. Langkah-langkah pelaksanaan metode drill sebagai berikut: 1) Pendidik memberi penjelasan singkat tentang konsep, prinsip, atau aturan yang menjadi dasar dalam melaksanakan pekerjaan yang akan dilatihkan, 2) pendidik mempertunjukkan bagaimana melakukan pekerjaan itu dengan baik dan benar sesuai dengan konsep dan aturan tertentu. Pada bentuk pelajar verbal yang dipertun jukkan adalah pengucapan atau penulisan kata atau kalimat, 3) jika belajar dilakukan secara kelompok atau klasikal, pendidik dapat memerintah salah seorang peserta didik untuk menirukan apa yang telah dilakukan pendidik, sementara siswa lain memperhatikan, 4) latihan perseorangan dapat dilakukan melalui bimbingan dari pendidik sehingga dicapai hasil belajar sesuai dengan tujuan. ${ }^{8}$

Proses pembelajaran pada prinsipnya merupakan proses pengembangan keseluruhan sikap kepribadian khususnya mengenai aktivitas dan kreatifitas peserta didik melalui berbagai interaksi dan pengalaman belajar. Pembelajaran merupakan aktualisasi kurikulum yang menuntut pendidik dalam menciptakan dan menumbuhkan kegiatan peserta didik sesuai dengan rencana yang telah diprogramkan. ${ }^{9}$ Pada hakekatnya pembelajaran adalah proses interaksi antara peserta didik dengan lingkungannya, sehingga terjadi perubahan perilaku ke arah yang lebih baik ${ }^{10}$. Berdasarkan pengertian yang disampaikan oleh Mulyasa di atas dapat disimpulkan bahwa pembelajaran merupakan sebuah interaksi proses belajar mengajar yang berlangsung untuk saling mempengaruhi dalam bentuk hubungan interaksi antara guru dan siswa dalam setiap proses pembelajaran merupakan suatu kegiatan yang sengaja diciptakan dengan tujuan untuk mengubah sikap dan perilaku serta meningkatkan pengetahuan.

\footnotetext{
76.

${ }^{8}$ Sumiati dan Azra, Metode Pembelajaran, Bandung: CV. Wacana Prima, 2008, hlm. 108

${ }^{9}$ E. Mulyasa, Implementasi Kurikulum 2004 Panduan Pembelajaran KBK, Bandung: Rosdakarya, 2004, hlm. 99

${ }^{10}$ E. Mulyasa, Kurikulum Berbasis Kompetensi, Konsep, Karakteristik, Implementasi, Bandung: Rosdakarya, 2003, hlm. 99
} 
Menurut Departemen Agama RI sejalan dengan petunjuk Al-Qur'an, secara garis besar pendidikan Islam diarahkan pada 2 tujuan utama yaitu upaya untuk memperoleh keselamatan hidup di dunia dan kesejahteraan hidup di akhirat. ${ }^{11}$ Berdasarkan penjelasan diatas maka disimpulkan bahwa tujuan pembelajaran PAI mengandung pengertian bahwa proses pendidikan agama Islam yang dilalui dan dialami oleh peserta didik di sekolah dimulai dari tahapan kognisi yakni pengetahuan dan pemahaman terhadap nilai-nilai ajaran Islam. Untuk selanjutnya menuju ke tahapan sikap yakni terjadinya proses interalisasi ajaran nilai-nilai ajaran Islam ke dalam diri peserta didik, melalui tahapan afeksi ini diharapkan dapat tumbuh motivasi dalam diri peserta didik dan bergerak untuk mengamalkan ajaran Islam (tahapan psikomotorik).

Adapun materi pembelajaran yang penulis ajarkan dengan menggunakan dengan metode drill adalah bacaan salat, keserasian gerakan salat dalam standar kompetensi melaksanakan salat, kompetensi dasar menghafal bacaan salat, menampilkan keserasian gerakan, dengan indikator melakukan gerakan salat dengan benar, menampilkan bacaan salat dengan benar, mempraktikkan salat fardlu dengan benar, menyebutkan rakaat dan waktunya salat fardlu, dengan tujuan pembelajaran mampu menghafal bacaan salat dan menampilkan keserasian gerakan salat dengan benar dan tertib. Kegiatan salat harus dibiasakan sejak dini, untuk mewujudkan pengamalan ibadah shalat maka diperlukan kesabaran, semangat, dan ketekunan yang tinggi dari guru pendidikan agama Islam dan senantiasa memberikan pembiasaan dalam pembinaan, bimbingan dan penyuluhan terhadap siswa sehingga dapat mendisiplinkan melaksanakan ibadah shalat dengan baik dan istiqomah. ${ }^{12}$

Kata salat berasal dari bahasa Arab ash-shalah yang berarti doa. Menurut istilah syariat (hukum) Islam shalat berarti serangkaian ibadah yang berupa ucapan dan gerakan yang di mulai dengan takbiratul ihram dan di akhiri dengan salam dengan syarat dan rukun tertentu. Ketentuan wajibnya shalat lima waktu di sebutkan dalam QS. Al Baqarah ayat 43 Dan dirikanlah shalat, tunaikanlah zakat dan ruku'lah beserta orangorang yang ruku". (QS. Al Baqarah ayat 43). Berdasarkan ayat tersebut menunjukkan

11 Departemen Agama RI, AL-Hikmah AL-Qur'an dan Terjemahnya, Bandung: Penerbit Diponegoro, 2006.

${ }_{12}$ Masnah, Peningkatan Kemampuan Menghafal Bacaan -Bacaan Shalat Dengan Menggunakan Metode Drill Di Awal Pelajaran Pada Siswa Kelas 7 Smp Negeri 1 Banjar Margo Kabupaten Tulang Bawang, Volume 2 nomor (02), 2018, hlm. 189-202 
bahwa shalat adalah wajib ditunaikan oleh setiap orang Islam dengan memenuhi syarat dan rukunnya.

Peserta didik dalam hal ini diharapkan mampu melaksanakan salat wajib dengan kemampuan menghafal bacaan-bacaannya, memenuhi syarat dan rukunnya sebagaimana yang telah diajarkan oleh guru pendidikan agama Islam. Menurut Kamus Bahasa Indonesia, kemampuan menghafal adalah Kemampuan untuk meresapkan ke dalam fikiran agar selalu ingat. Sedanngkan kata Bacaan dapat diartikan yang dibaca (diucapkan). Dalam konteks ibadah salat bacaan yang harus diucapkan adalah berupa lafadz yaitu tulisan dalama Bahasa Al Qur'an atau Bahasa Arab.

Berdasarkan uraian di atas dapat disimpulkan bahwa "Kemampuan menghafal bacaan-bacaan dalam shalat wajib" mengandung arti "Kecakapan /keahlian di dalam mengucapkan lafadz-lafadz dalam shalat wajib tanpa melihat dari sumber yang ada”. Shalat wajib adalah ibadah yang terdiri dari gerakan-gerakan dan bacaan-bacaan atau perkataan-perkataan mulai dari takbiratul ihram dan di akhiri dengan salam dengan memenuhi beberapa syarat yang ditentukan. ${ }^{13}$

\section{B. METODE PENELITIAN}

Metode penelitian yang digunakan yaitu Penelitian Tindakan Kelas (PTK) yang terdiri atas siklus I dan siklus II. Penelitian ini dilakukan dengan menerapkan beberapa tahap prosedur penelitian diantaranya (1) mengidentifkasi masalah, (2) analisis dan perumusan masalah, dan (3) rencana perbaikan yang terdapat tindakan berupa siklus I dan siklus II. Rencana perbaikan pembelajaran Siklus I berupa tindakan kepada siswa dibimbing untuk memahami cara melaksanakan ibadah shalat. Setelah itu, diberikan latihan-latihan soal secara individu atau kelompok. Rencana perbaikan Siklus II berupa tindakan terhadap siswa dibimbing cara langkah-langkah untuk melaksanakan ibadah shalat. Kemudian, memberikan latihan-latihan soal.

Penelitian tindakan kelas (PTK) ini dilaksanakan di SDN Sekaran 02 Gunungpati Semarang yang beralamat di Jl. Raya Sekaran Gunungpati Semarang pada tanggal 23 Februari sampai 8 Maret 2018. Penentuan waktu penelitian mengacu pada kalender akademik sekolah dan silabus pembelajaran mata pelajaran PAI kelas III semester genap. Subjek pelaku tindakan adalah guru PAI kelas III SDN Sekaran 02 Gunungpati

\footnotetext{
${ }^{13}$ Rasyid, Sulaiman, Fikih Islam/, Jakarta: Sinar Baru Algensindo, 2005
} 
Semarang. Sedangkan subjek penerima tindakan adalah peserta didik kelas III SDN Sekaran 02 Gunungpati Semarang yang berjumlah 20 peserta didik yang terdiri dari 15 peserta didik putra dan 5 peserta didik putri.

Metode pengambilan data yang digunakan yaitu metode kuesioner dan metode interview atau wawancara. Metode kuesioner ini penulis gunakan sebagai bahan ataupun data untuk penelitian, baik mengenai pelaksanaan ibadah shalatnya maupun tentang kepribadiannya. Sedangkan, metode interview digunakan untuk mendapatkan data dari kepala sekolah dan guru agama islam. Metode interview yang dilakukan pada kepala sekolah untuk memperoleh data tentang situasi umum sekolah yang meliputi: sejarah berdirinya, struktur organisasi, kedaan guru dan siswa, serta fasilitas yang dimilikiya. Sedangkan dari guru agama Islam penulis menanyakan tentang metode yang diterapkan supaya pelajar aktif dalam melaksanakan ibadah salat.

Langkah analisis data yaitu; 1) menentukan nilai tes individu berdasarkan skor teoritis, 2) menentukan rata-rata hasil belajar peserta didik, dan 3) menentukan nilai ketuntasan klasikal.Data yang diperoleh dianalisis dengan menggunakan analisis deskriptif $^{14}$. Data yang dianalisis meliputi data tes hasil belajar siswa, hasil pengamatan aktivitas siswa pada proses pembelajaran dengan metode drill, data respon siswa terhadap kegiatan pembelajaran dengan metode drill, dan data keterampilan guru dalam mengelola pembelajaran dengan pendekatan dengan metode drill. Kriteria pengkategorian masing-masing data adalah:

1. Analisis data tes hasil belajar siswa dilakukan dengan tes siswa secara individu yaitu memberi skor 1 untuk setiap butir tes yang dijawab benar dan memberikan skor 0 untuk setiap butir soal yang dijawab salah.

2. Hasil pengamatan aktivitas siswa dianalisis secara deskriptif dengan menggunakan statistik presentase. Rumus yang digunakan adalah :

Presentase $(\%)=\mathrm{A} / \mathrm{B} \times 100 \%$

$\mathrm{A}=$ Frekuensi yang muncul

$\mathrm{B}=$ Jumlah Siswa

3. Analisis dan respon siswa diambil dari angket pengisian siswa yang menjadi responden dengan menggunakan statistik persentase

\footnotetext{
${ }^{14}$ Wijayama, B, Peningkatan Hasil Belajar IPA dan Karakter Rasa Ingin Tahu Melalui Model Problem Based Learning Peserta Didik Kelas VI. Jurnal Kreatif: Jurnal Kependidikan Dasar, 10(2), 2020, hlm.190-198.
} 
4. Analisis data keterampilan guru dalam mengelola pembelajaran dengan pendekatan metode drill dilakukan dengan memberikan cek pada kategori yang diamati, yaitu : a) kolom angka 1 bila aspek yang dilakukan guru tidak baik, 2) kolom angka 2 bila aspek yang dilakukan guru kurang baik, 3) kolom angka 3 bila aspek yang dilakukan guru cukup baik, dan 4) kolom angka 4 bila aspek yang dilakukan guru baik

Indikator keberhasilan dalam penelitian ini yakni dilihat dari perolehan nilai siswa dalam mata pelajaran Pendidikan Agama Islam khususnya dalam melaksanakan gerakan salat dengan benar, membaca gerakan salat dengan benar, mempraktikkan salat fardlu dengan benar, dan siswa dapat menyebutkan rakaat dan waktu salat fardlu di kelas 3 SD Negeri Sekaran 02 Gunungpati Semarang.

\section{HASIL PENELITIAN DAN PEMBAHASAN}

Hasil dari penelitian ini mengungkapkan bahwa sejumlah 60\% dari jumlah siswa kelas III semester II SD Negeri Sekaran 02 Gunungpati Semarang mendapatkan nilai rendah dalam pembelajaran Pendidikan Agama Islam pada kompetensi dasar menghafal bacaan salat dan menampilkan keserasian gerakan. Hal ini disebabkan oleh penjelasan guru yang kurang dipahami, guru kurang mengkondisikan siswa, kurangnya latihan siswa maka penulis berupaya untuk meningkatkan partisipasi belajar siswa kelas III semester II SD Negeri Sekaran 02 Gunungpati Semarang pada mata pelajaran Pendidikan Agama Islam dalam kompetensi dasar menghafal bacaan salat menampilkan keserasian gerakan shalat melalui metode drill. Dengan menggunakan metode drill ternyata hasil belajar siswa kelas III semester II pada kompetensi dasar menghafal bacaan salat dan menampilkan keserasian gerakan shalat di sini guru memberi penjelasan dengan metode drill, mengkoordinasikan siswa daalam kegiatan belajar mengajar, memperbanyak latihan, dan memberi bimbingan kepada siswa.

Setelah dilaksanakan dua siklus perbaikan diperoleh data dengan persentase nilai tuntas yaitu siswa yang memperoleh nilai sama atau lebih dari Kriteria Ketuntasan Minimal (KKM): 66 sebagai berikut: 1) sebelum siklus perbaikan nilai tuntas $25 \%$ dari 20 siswa (5 siswa), 2) perbaikan siklus I nilai tuntas $60 \%$ dari 20 siswa (12 siswa), dan 3) perbaikan siklus II nilai tuntas $80 \%$ dari 20 siswa (16 siswa). 


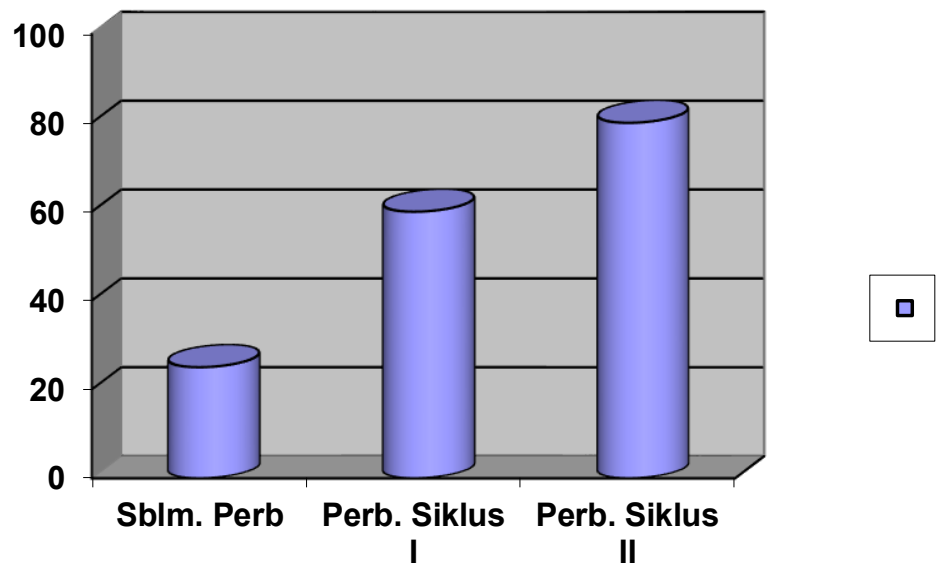

\section{Gambar 1. Ketuntasan Pembelajaran Pendidikan Agama Islam}

Berdasarkan grafik ketuntasan pembelajaran Pendidikan Agama Islam, dapat diketahui bahwa sebelum perlakuan nilai peserta didik belum mencpai nilai Kriteria Ketuntasan Minimal (KKM). Setelah dilakukan adanya perbaikan pada siklus I memperoleh rata-rata nilai 60 . Kemudian, setelah dilakukan perbaikan siklus II diperoleh nilai rata-rata 80 dengan kriteria tuntas.

Tabel 1. Data Nilai Rata-rata Pembelajaran Pendidikan Agama Islam Sebelum Perbaikan

\begin{tabular}{|c|c|c|c|c|}
\hline No & Nilai & Jumlah Siswa & Jumlah Nilai & Keterangan \\
\hline 1 & 40 & 1 & 40 & \\
\hline 2 & 46 & 5 & 230 & \\
\hline 3 & 53 & 7 & 371 & \\
\hline 4 & 60 & 2 & 120 & \\
\hline 5 & 66 & 4 & 264 & \\
\hline 6 & 80 & 1 & 80 & \\
\hline \multicolumn{2}{|c|}{ Jumlah } & 20 & 1105 & \\
\hline \multicolumn{2}{|c|}{ Rata-rata } & & 55,25 & \\
\hline
\end{tabular}

Keterangan :

a. Siswa yang mendapat nilai kurang dari 66 sebanyak 15 anak $=75 \%$.

b. Siswa yang mendapat nilai lebih atau sama dengan 66 sebanyak 5 anak $=25 \%$.

Berdasarkan tabel tersebut dapat diketahui peningkatan nilai rata-rata kelas III semeter II SD Negeri 02 sekaran Semarang. Kondisi awal nilai rata-rata siswa sebesar 25. Setelah dilakukan tindakan pada siklus I (pembelajaran Pendidikan agama Islam Materi Gerakan dan Bacaan Salat dengan metode drill) diketahui hasil pembelajaran 
siswa mengalami peningkatan. Hal ini terbukti dengan hasil tes materi gerakan dan bacaan salat pada siklus I adalah 60,00. Nilai rata-rata siswa dari prasiklus ke siklus I meningkat. Nilai rata-rata materi gerakan dan bacaan salat dari siklus I ke siklus II menjadi 80,00. Secara keseluruhan, peningkatan nilai rata-rata materi gerakan dan bacaan salat dari prasiklus sampai ke siklus II sebesar $40 \%$.

Perubahan perilaku siswa setelah diterapkan pembelajaran pendidikan agama islam materi gerakan dan bacaan salat menggunakan metode $d r i l l$, mengalami perubahan ke arah yang positif. Perubahan perilaku siswa dapat diketahui dari hasil observasi. Perbandingan hasil observasi siklus I dan siklus II menunjukkan secara jelas adanya perubahan perilaku siswa ke arah positif.

\section{Kegiatan Persiklus}

\section{Tabel 2. Data Nilai Rata-rata Pembelajaran Pendidikan Agama Islam Perbaikan}

Siklus I

\begin{tabular}{|c|c|c|c|}
\hline No & \multicolumn{1}{|c|}{ Nilai } & Jumlah Siswa & Jumlah Nilai \\
\hline 1 & 46 & 3 & 138 \\
\hline 2 & 53 & 3 & 159 \\
\hline 3 & 60 & 2 & 120 \\
\hline 4 & 66 & 3 & 198 \\
\hline 5 & 80 & 6 & 438 \\
\hline 6 & 70 & 3 & 240 \\
\hline \multicolumn{2}{r|}{ Jumlah } & 20 & 1293 \\
\hline \multicolumn{2}{r|}{ Rata-rata } & & 64,65 \\
\hline
\end{tabular}

Keterangan :

a. Siswa yang mendapat nilai kurang dari 66 sebanyak 8 anak $=40 \%$.

b. Siswa yang mendapat nilai lebih atau sama dengan 66 sebanyak 12 anak $=60 \%$.

Berdasarkan tabel 2. tersebut dapat diketahui nilai rata-rata peserta didik untuk materi gerakan dan bacaan salat pada siklus I adalah 64,65. Hasil pembelajaran tersebut masih di bawah KKM (66). Kegiatan selanjutnya, siklus II, diharapkan kemampuan siswa lebih meningkat lagi dari nilai yang telah diperoleh.

Hasil nontes siklus I data didapatkan dari hasil observasi, wawancara, dan dokumentasi. Berdasarkan observasi dapat diketahui bahwa siswa yang memperhatikan penjelasan guru dengan sungguh-sungguh terdapat 12 siswa $(60 \%)$ mendapatkan nilai lebih atau sama dengan 66. Terdapat 8 siswa (40\%) yang tidak memperhatikan penjelasan guru dengan sungguh-sungguh sehingga mendapatkan nilai kurang dari 66. Berdasarkan hasil observasi dapat diketahui bahwa perilaku siswa pada siklus I masih 
belum menunjukkan hasil yang positif. Oleh karena itu, guru perlu melakukan perbaikan dalam pembelajaran selanjutnya. Hal ini dimaksudkan agar ada perubahan perilaku siswa ke arah yang lebih positif.

\section{Tabel 3. Data Nilai Rata-rata Pembelajaran Pendidikan Agama Islam Perbaikan}

\section{Siklus II}

\begin{tabular}{|c|c|c|c|c|}
\hline No & Nilai & Jumlah Siswa & Jumlah Nilai & Keterangan \\
\hline 1 & 40 & - & - & \\
\hline 2 & 50 & 2 & 100 & \\
\hline 3 & 60 & 2 & 120 & \\
\hline 4 & 70 & 8 & 560 & \\
\hline 5 & 80 & 5 & 400 & \\
\hline 6 & 90 & 3 & 270 & \\
\hline 7 & 100 & - & - & \\
\hline & Jumlah & 20 & 1450 & \\
\hline & Rata-rata & & 72,50 & \\
\hline
\end{tabular}

Keterangan:

a. Siswa yang mendapat nilai kurang dari 66 sebanyak 4 anak $=20 \%$.

b. Siswa yang mendapat nilai lebih atau sama dengan 66 sebanyak 16 anak $=80 \%$.

Berdasarkan tabel tersebut nilai rata-rata siswa untuk pembelajaran pendidikan agam islam materi gerakan dan bacaan salat memperoleh nilia rata-rata 72,50 yang yang menunjukkan sudah diatas KKM yakni 66.

Hasil observasi pada siklus II (hasil nontes) menunjukkan bahwa perilaku siswa sudah lebih positif dibandingkan pada siklus I. Meskipun belum semua siswa berperilaku dengan baik, tetapi perilaku negatif siswa telah berkurang. Berdasarkan tabel 3 tersebut, dapat diketahui bahwa pada aspek pertama (sebagian besar siswa memperhatikan penjelasan guru dengan sungguh-sungguh) diperoleh data yaitu ada 16 siswa (80,00\%). Sebanyak empat siswa (20\%) tidak memperhatikan penjelasan guru dengan sungguh-sungguh. Sebagian besar siswa sudah mulai terkondisikan, siswa dengan penuh konsentrasi mendengarkan penjelasan guru. 


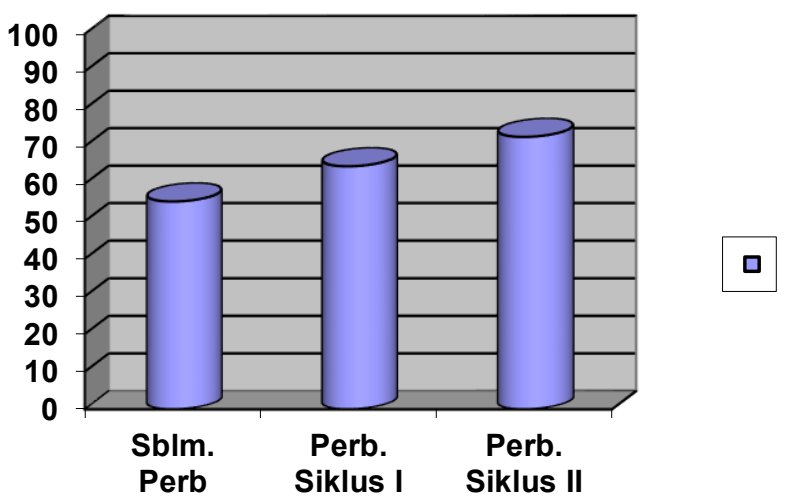

\section{Gambar 2. Perbaikan pembelajaran Pembelajaran Pendidikan Agama Islam}

Berdasarkan gambar 2. di atas, dapat diketahui bahwa dari perbaikan pembelajaran yang dilakukan selama dua siklus menunjukkan hasil prestasi siswa yang menggembirakan. Hal ini dapat dilihat dari perolehan nilai rata-rata siswa mata pelajaran Pendidikan Agama Islam, pada materi gerakan dan bacaan salat pada perbaikan siklus I sebesar 64,65. Nilai rata-rata siswa dalam mata pelajaran Pendidikan Agama Islam, pada materi gerakan dan bacaan salat mengalami peningkatan pada nilai perbaikan siklus II sebesar 72,50.

Kemajuan dalam prestasi siswa dari dua kali perbaikan pembelajaran berkat hasil refleksi guru dan hasil diskusi dengan teman sejawat. Disamping itu kejelian penulis dalam mengevaluasi segala permasalahan yang dihadapi siswa dengan metode yang tepat. Namun demikian, tidak semua siswa mengerjakan soal sesuai dengan waktu yang tersedia, Perbaikan yang terjadi dalam pembelajaran adalah guru harus memperhatikan tingkat kemampuan masing-masing individu, sehingga pada akhirnya tujuan pembelajaran akan tercapai dengan hasil yang memuaskan.

Penggunaan media pembelajaran baik yang berupa benda nyata seperti demonstrasi maupun model serta gambar-gambar yang sesuai dengan metode drill yaitu dengan latihan-latihan ternyata berdampak positif terhadap proses pembelajaran dan hasil belajar di kelas. Penggunaan metode drill sangat tepat jika disertai ketrampilan guru menggunakan media pembelajaran yang tepat pula. Sehingga guru mampu membangkitkan minat belajar siswa pada materi pokok menghafal bacaan salat serta menampilkan keserasian gerakan. Dari pengamatan/refleksi $80 \%$ siswa tampak berminat dan siap mempelajari materi pokok menghafal bacaan salat serta menampilkan 
keserasian gerakan. Selain itu partisipasi siswa selama proses pembelajaranpun meningkat, sekitar $80 \%$ siswa berani bertanya, mengeluarkan pendapat dan melakukan latihan-latihan salat dengan tertib.

Penerapan pembelajaran metode drill dalam Pendidikan Agama Islam di SD Sekaran 02 Gunungpati Semarang. Anak mula-mula mengamati apa yang dicontohkan guru, tentunya ada anak yang cukup hanya mengamati satu kali saja ada juga yang harus mengamati berulang-ulang. Sebagian hanya bekerja matanya saja, sebagian lagi mengamati sambil menggerakkan anggota badannya. Jadi mengamati tidak hanya melihat, tetapi perasaan otot ikut bekerja sehingga dapat membangun bayangan gerak. Setelah bayangan gerak tersebut kemudian latihan dapat dicoba, sehingga akan terlaksana pola geraknya. Setelah seluruh anak mencoba gerakan shalat dan menghafal bacaan, guru menghentikan latihan untuk memberikan koreksi. Kesalahan-kesalahan ditujukan secara umum saja dan memperjelas contoh yang diberikan. Kalau perlu diberi contoh lagi. Pengulangan-pengulangan terhadap latihan harus terus berjalan meskipun koreksi terus dilakukan anak-anak tidak boleh terganggu konsentrasinya. Koreksi secara individu /perorangan, kesalahan-kesalahan terhadap perorangan perlu ditunjukkan dan diperbaiki. Apabila kesalahan tidak terjadi lagi, dapat diharapkan bentuk latihan /gerak akan terjadi otomatis, artinya gerak dapat dilakukan tanpa dipikir lagi, gerak sudah menjadi satu dengan dirinya. Dengan demikian keserasian gerakan salat apabila menggunakan metode drill sangat cocok dan sesuai.

Ternyata tingginya minat dan partisipasi siswa berdampak pada tingkat pemahaman mata pelajaran Pendidikan Agama Islam. Hal ini terbukti dengan perolehan hasil belajar yang lebih baik dari sebelumnya (yang mendapat nilai sama atau lebih dari KKM: 66, semula hanya 5 anak, sekarang 16 anak dari jumlah siswa yaitu 20 anak), pembelajaran Pendidikan Agama Islam dengan memanfaatkan metode drill (latihan) ternyata dapat meningkatkan hasil belajar siswa. Dengan demikian pelaksanaan Pendidikan Agama Islam dengan menggunakan metode drill ternyata sangat efektif khususnya dalam materi menampilkan keserasian gerakan shalat dan bacaan shalat.

\section{SIMPULAN}

Pelaksanaan pembelajaran Pendidikan Agama Islam di SD Negeri Sekaran 02 Gunungpati Semarang. Perbaikan pembelajaran dari dua siklus untuk mata pelajaran Pendidikan Agama Islam telah mampu menciptakan perubahan yang sangat signifikan, 
baik dalam proses pembelajaran persentase jumlah siswa yang mencapai ketuntasan belajar, maupun persentase hasil belajar rata-rata. Dalam proses pembelajaran terbukti sebagai berikut: 1) suasana kelas lebih hidup dengan keaktifan siswa yang terlibat dalam pembelajaran melalui kegiatan tugas kelompok secara langsung. 2) siswa ikut terlibat aktif dalam menggunakan alat pembelajaran, dan 3) latihan dari tanya jawab yang aktif dan komunikatif antara guru dan siswa dapat membantu siswa yang mengalami kesulitan dalam menjawab pertanyaan.

Penerapan pembelajaran metode drill dalam Pendidikan Agama Islam di SD Sekaran 02 Gunungpati Semarang Anak mula-mula mengamati apa yang dicontohkan guru, tentunya ada anak yang cukup hanya mengamati satu kali saja ada juga yang harus mengamati berulang-ulang. Sebagian hanya bekerja matanya saja, sebagian lagi mengamati sambil menggerakkan anggota badannya. Jadi mengamati tidak hanya melihat, tetapi perasaan otot ikut bekerja sehingga dapat membangun bayangan gerak. Setelah bayangan gerak tersebut kemudian latihan dapat dicoba, sehingga akan terlaksana pola geraknya. Setelah seluruh anak mencoba gerakan shalat dan menghafal bacaan, guru menghentikan latihan untuk memberikan koreksi. Kesalahan-kesalahan ditujukan secara umum saja dan memperjelas contoh yang diberikan. Kalau perlu diberi contoh lagi. Pengulangan-pengulangan terhadap latihan harus terus berjalan meskipun koreksi terus dilakukan anak-anak tidak boleh terganggu konsentrasinya. Koreksi secara individu/perorangan, kesalahan-kesalahan terhadap perorangan perlu ditunjukkan dan diperbaiki. Apabila kesalahan tidak terjadi lagi, dapat diharapkan bentuk latihan/gerak akan terjadi otomatis, artinya gerak dapat dilakukan tanpa dipikir lagi, gerak sudah menjadi satu dengan dirinya. Dengan demikian keserasian gerakan shalat apabila menggunakan metode drill sangat cocok dan sesuai.

Setelah dilaksanakan dua siklus perbaikan diperoleh data dengan persentase nilai tuntas yaitu siswa yang memperoleh nilai sama atau lebih dari Kriteria Ketuntasan Minimal (KKM) : 66 sebagai berikut : 1) Sebelum siklus perbaikan nilai tuntas $25 \%$ dari 20 siswa (5 siswa), 2) Perbaikan siklus I nilai tuntas $60 \%$ dari 20 siswa (12 siswa), 3) Perbaikan siklus II nilai tuntas $80 \%$ dari 20 siswa (16 siswa).

Perbaikan pembelajaran yang dilakukan selama dua siklus menunjukkan hasil prestasi siswa yang menggembirakan. Hal ini dapat dilihat dari perolehan nilai siswa dalam mata pelajaran Pendidikan Agama Islam, pada materi pembahasan ibadah salat. 
Untuk menentukan indikator keberhasilan peneliti melakukan dengan melihat dari perolehan nilai siswa dalam mata pelajaran Pendidikan Agama Islam khususnya dalam melaksanakan gerakan salat dengan benar, membaca gerakan salat dengan benar, mempraktikkan salat fardlu dengan benar, dan siswa dapat menyebutkan rakaat dan waktu salat fardlu di kelas 3 SD Negeri Sekaran 02 Gunungpati Semarang meskipun metode drill mempunyai kelebihan dan kekurangan.

Keefektifan pelaksanaan Pembelajaran Pendidikan Agama Islam dengan menggunakan metode drill. Penggunaan istilah "latihan" sering disamakan artinya dengan istilah "ulangan". Padahal maksudnya berbeda. Latihan bermaksud agar pengetahuan dan kecakapan tertentu dapat dimiliki dan dikuasai sepenuhnya oleh peserta didik. Sedangkan ulangan hanyalah untuk sekedar mengukur sejauh mana dia telah menyerap pembelajaran tersebut. Dengan menggunakan metode drill ternyata hasil belajar siswa kelas III semester II pada kompetensi dasar menghafal bacaan shalat dan menampilkan keserasian gerakan salat sangat efektif. 


\section{DAFTAR PUSTAKA}

Achmadi, Ideologi Pendidikan Islam. Yogyakarta: Pustaka Pelajar, 2005

Anisa, R, Meningkatkan Pelaksanaan tata cara shalat melalui metode kinestik bagi siswa tuna grahita. E-JUPEku, 2016

Arief, Armai, Pengantar Ilmu dan Metodologi Pendidikan Islam. Jakarta: Intermasa, 2002

Arikunto, Suharsimi., Suhardjono, dan Supardi, Penelitian Tindakan Kelas. Jakarta: Bina Aksara, 2006

Chabib, Thoha, Kapita Selekta Pendidikan Islam. Yogyakarta: Pustaka Pelajar, 1996

Departemen Agama RI, AL-Hikmah AL-Qur'an dan Terjemahnya, Bandung: Penerbit Diponegoro, 2006.

Djamarah, Syaiful Bahri, Strategi Belajar Mengajar. Jakarta: Rineka Cipta, 2010

E. Mulyasa, Kurikulum Berbasis Kompetensi, Konsep, Karakteristik, Implementasi, Bandung: Rosdakarya, 2003

E. Mulyasa, Implementasi Kurikulum 2004 Panduan Pembelajaran KBK, (Bandung: Rosdakarya, 2004

Hawi, Akmal. Pendidikan Agama Islam. Palembang: Excellen Publishing, 2008.

Masnah, Peningkatan Kemampuan Menghafal Bacaan-Bacaan Shalat Dengan Menggunakan Metode Drill Di Awal Pelajaran Pada Siswa Kelas 7 Smp Negeri 1 Banjar Margo Kabupaten Tulang Bawang. Volume 2 nomor (02), 2008.

Nata, Abuddin, Pemikiran Para Tokoh Pendidikan Islam. Jakarta: Raja Grafindo Persada, 2001

Rasjid, H. Sulaiman, Fiqih Islam. Bandung: PT. Sinar Baru Algensindo, 2002

Rasyid, Sulaiman, Fikih Islam/. Jakarta: Sinar Baru Algensindo, 2005

Roestiyah, Strategi Belajar Mengajar. Jakarta: Rineka Cipta, 2008

Sumiati dan Azra, Metode Pembelajaran. Bandung: CV. Wacana Prima, 2008

Suparno, Mengembangkan Profesionalitas Guru. Jakarta: Depdiknas, 2008

Sudjana, Nana, Berbagai Metode Pembelajaran Aktif dan Kreatif. Jakarta: Bumi Aksara, 2012 
Sugiyono, Dasar-dasar Statistik Pendidikan. Bandung: Alfabeta, 2013

Utomo, Cahyo Budi, Pengembangan Instrumen dalam PTK, Karya Tulis Ilmiah dalam Kegiatan Pengembangan Profesi Guru, Semarang: Lemlit UNNES, 2006.

Wijayama, B, Peningkatan Hasil Belajar IPA dan Karakter Rasa Ingin Tahu Melalui Model Problem Based Learning Peserta Didik Kelas VI. Jurnal Kreatif: Jurnal Kependidikan Dasar, 10(2), 2020 